\title{
Effect of Altitude on Oxygen Binding by Hemoglobin and on Organic Phosphate Levels
}

\author{
Claude Lenfant, John Torrance, Eugenia English, Clement A. Finch, \\ Cesar Reynafarje, Jose Ramos, and Jose Faura
}

From the Departments of Medicine and of Physiology and Biophysics, University of Washington School of Medicine, Seattle, Washington 98105, and the Faculty of Medicine, Universidad Nacional Mayor de San Marcos, Lima, Peru

A в S T R A C T The relationship between oxygen dissociation and 2,3-diphosphoglycerate (2,3DPG) in the red cell has been studied in subjects moving from low to high altitude and vice versa. Within $24 \mathrm{hr}$ following the change in altitude there was a change in hemoglobin affinity for oxygen; this modification therefore represents an important rapid adaptive mechanism to anoxia. A parallel change occurred in the organic phosphate content of the red cell. While this study does not provide direct evidence of a cause-effect relationship, the data strongly suggest that with anoxia, the observed rise in organic phosphate content of the red cell is responsible for increased availability of oxygen to tissues.

\section{INTRODUCTION}

At high altitude the affinity of hemoglobin for oxygen is decreased to make hemoglobin-bound oxygen more available to body tissues (1). There is little information on the manner in which this effect is accomplished. Recently Benesch and Benesch (2), Benesch, Benesch, and $\mathrm{Yu}$ (3), and Chanutin and Curnish (4) demonstrated that the affinity of a hemoglobin solution for oxygen may be decreased by its interaction with organic phosphates, particularly 2,3-diphosphoglycerate (2,3DPG) (5). Since this compound is a major component of red cell organic phasphate, it may play an important role in controlling the equilibrium of oxygen with hemoglobin in vivo. The pres-

Received for publication 10 July 1968. ent study was undertaken to examine precise changes of the oxygen dissociation curve as an early adaptive mechanism to changes in environmental oxygen partial pressure, and to determine the relationship between oxygen dissociation and red cell organic phosphate concentration in subjects moved from one altitude to another.

\section{METHODS}

Seven subjects who resided at sea level in Lima, Peru, were taken to Morococha (elevation $4530 \mathrm{~m}, \mathrm{Po}_{2}=84$ $\mathrm{mm} \mathrm{Hg}$ ) where they stayed for $144 \mathrm{hr}$ before returning to sea level. Before ascent, baseline values for $\mathrm{O}_{2} \mathrm{Hb}$ dissociation of intact red cells and hemolysates, blood organic phosphates, and standard hematologic measurements were obtained. Hematologic values are reported elsewhere. ${ }^{1}$ Further values were obtained during the 6 day period at high altitude and again at sea level. A second group of six subjects who resided in Morococha were studied there and after their descent to sea level. Venous blood collected in heparin was used in all measurements.

Oxygen dissociation curve. The $\mathrm{O}_{2} \mathrm{Hb}$ dissociation curve was measured by the mixing technique (6) whereby saturation is predetermined and $\mathrm{Po}_{2}$ is the unknown parameter. Each sample was divided into two equal portions, of which one was totally reduced and the other fully oxygenated by equilibration at $37^{\circ} \mathrm{C}$. The samples were then mixed to achieve approximately $50 \%$ saturation, and the partial pressure of oxygen and the $\mathrm{pH}$ were measured in this mixture. To standardize the results, two corrections were made. One consisted of converting the measured $\mathrm{Po}_{2}$ to that of a saturation of $50 \%$ using Hill's expression $\left(\log S / 100-S=\mathrm{n} \log \mathrm{Po}_{2}\right.$, in which $n=$ 2.65) and the other of correcting $\mathrm{PO}_{2}$ for a $\mathrm{pH}$ of 7.4 us-

1 Faura, J., J. Ramos, C. Reynafarje, E. English, P. Finne, and C. A. Finch. Effects of altitude on erythropoiesis. In preparation. 
ing the factor $\Delta \log \mathrm{Po}_{2} / \Delta \mathrm{pH}=-0.48$ (7). All the results given in this paper are expressed as the oxygen tension in millimeters of mercury required to obtain an oxygen saturation of $50 \%$ at $37^{\circ} \mathrm{C}$ and $\mathrm{pH} 7.4$ [ $\mathrm{P}_{\mathrm{so}}(7.4)$ ]. This $\mathrm{P}_{\mathrm{5} 0}$ was also determined in hemolysates prepared by the addition of saponin prior to equilibration.

The $\mathrm{PO}_{2}$ and $\mathrm{pH}$ were measured using a Beckman 160 gas analyzer equipped with a Beckman macro $\mathrm{PO}_{2}$ electrode (Beckman Instruments, Inc., Fullerton, Calif.) mounted in a microcuvette $(0.03 \mathrm{ml})$ and a micro $\mathrm{pH}$ assembly.

Organic phosphates. $4 \mathrm{ml}$ of blood were pipetted into centrifuge tubes, and the cells were washed three times with cold saline. The white cells were not removed with the supernatant since it was established that white cells contain only about $3 \%$ of the 2,3-DPG in normal blood. The acid-soluble phosphates in packed cells were extracted and separated according to the method of Robinson, Loder, and deGruchy (8). The method was modified so that four fractions were collected. These fractions contained the following compounds:

(a) $50 \mathrm{ml}$ water $+50 \mathrm{ml} 0.02 \mathrm{~N} \mathrm{HCl-inorganic} \mathrm{phosphate,} \mathrm{AMP,}$

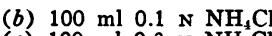

(c) $100 \mathrm{ml} \quad 0.2 \mathrm{~N}^{\mathrm{NH}_{4}} \mathrm{Cl}$ ADP hexose monophos-
phates, TPN, MPG,
-hexose diphosphates,
-2,3-DPG,
-ATP

The fractions were analyzed for total phosphate content using the method of Bartlett (9). Using this technique we were able to recover $85-90 \%$ of $2,3-\mathrm{DPG}$ or ATP added to a hemolysate before extraction. The range of values for 2,3-DPG and ATP in 12 normal subjects residing in Seattle was for 2,3-DPG, $186-309 \mu \mathrm{gP} / \mathrm{ml}$ packed cells (mean 229, sD 34); and for ATP, 71-100 $\mu \mathrm{gP} / \mathrm{ml}$ packed cells (mean 80 , sD 7.6 ). These values are similar to those reported by Robinson et al. (8).

\section{RESULTS}

Group I. The $\mathrm{P}_{50}$ sea level value of $26.6 \mathrm{~mm}$ $\mathrm{Hg}(\mathrm{SD} \pm 0.3)$ of the first group increased to 28.6 \pm 0.6 within $12 \mathrm{hr}$ after ascent to Morococha and to $31.0 \pm 0.4$ at $36 \mathrm{hr}$. This increase was sustained during the 5 days at high altitude but fell after descent and was found to be $27.3 \pm 0.7$ by $60 \mathrm{hr}$ (Fig. 1).

The mean concentration of 2,3-DPG at sea level was $90 \pm 11 \mu \mathrm{g}$ phosphorus $/ \mathrm{ml}$ of blood. This increased to $142 \pm 8$ at $36 \mathrm{hr}$ after moving to high altitudes; at $132 \mathrm{hr}$ it was $140 \pm 10$. After return to sea level this value fell to $87 \pm 13$.

Group II. Natives of Morococha had a $\mathrm{P}_{50}$ of $30.7 \pm 0.6 \mathrm{~mm} \mathrm{Hg}$ and a 2,3-DPG concentration of $155 \pm 14 \mu \mathrm{g}$ phosphorus $/ \mathrm{ml}$ of blood. On descent to sea level the $\mathrm{Po}_{2}$ decreased to $28.6 \pm 0.5$ $\mathrm{mm} \mathrm{Hg}$ of $12 \mathrm{hr}$ and to $27.3 \pm 0.8$ at $36 \mathrm{hr}$. The corresponding level of 2,3-DPG at $36 \mathrm{hr}$ was $109 \pm 13$. The final measurements made $84 \mathrm{hr}$ after descent showed a $\mathrm{Po}_{2}$ of $28.3 \pm 0.6$ and a 2,3DPG level of $87 \pm 14$. These changes are shown in Fig. 2.

Changes in the same direction occurred in the ATP content of the red cell, but proportionately to 2,3-DPG, these amounted to only $1 / 10$ in group I and $1 / 3$ in group II. Changes in the phosphate content of fractions 1 and 2 were negligible. In both groups the $\mathrm{P}_{50}$ of hemolyzed blood was parallel to, but much lower than changes in whole blood (Tables I and II).

The mean reticulocyte count of subjects in group I was less than $2 \%$ during the first 2 days at high altitude and less than $5 \%$ during the 1 st week. ${ }^{1}$ Thus the changes observed could not be ascribed to any significant ingress of young erythrocytes.

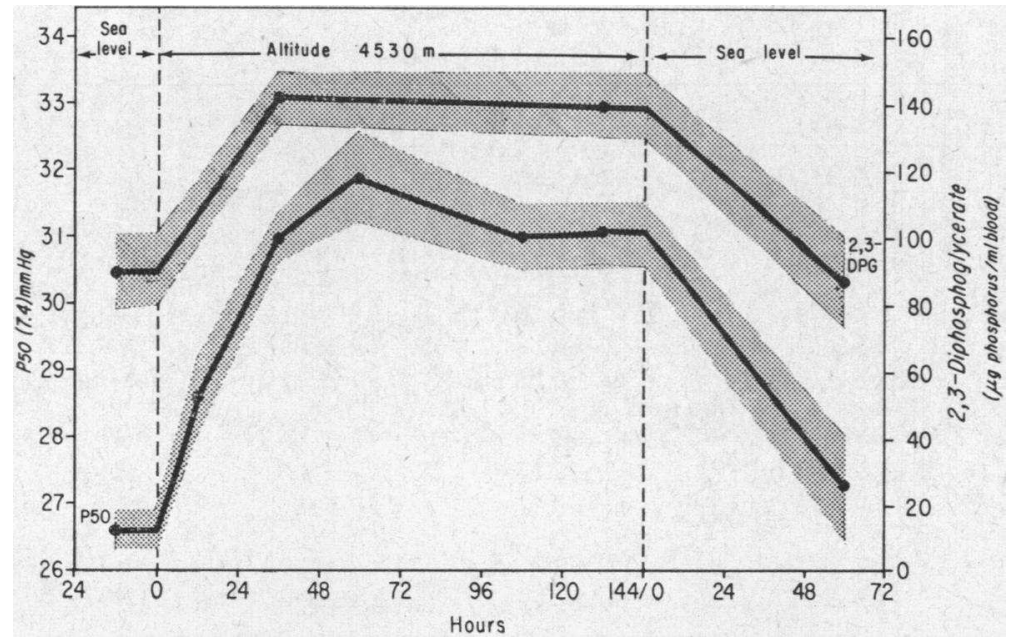

Figure 1 Changes in $P_{50}$ (7.4) and 2,3-DPG of whole blood induced by high altitude. Mean values are shown by the lines, one standard deviation is indicated by the shaded area. Parallel increases with exposure to high altitude and decreases on return to sea level were observed. 


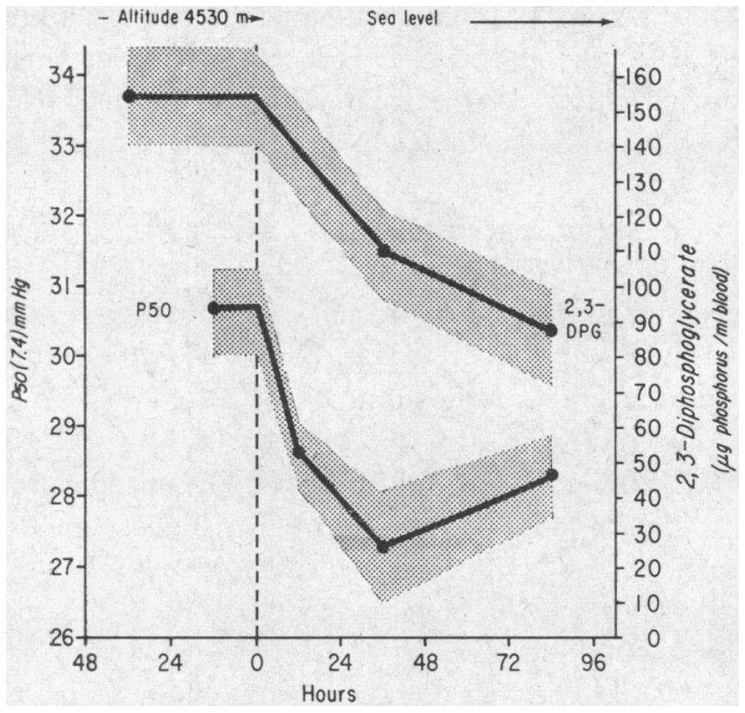

FIgURE 2 Changes in $P_{50}$ (7.4) and 2,3-DPG of whole blood in natives of high altitude on descent to sea level. The shaded area represents one standard deviation.

\section{DISCUSSION}

The present study shows that in response to high altitude hypoxia, the shift of the $\mathrm{O}_{2} \mathrm{Hb}$ dissociation curve occurs rapidly. Within 2 days after ascent to $4530 \mathrm{~m}$, the $P_{50}$ of lowlanders reached the value prevailing in residents of the highlands. This change provides an important physiological advantage by making more oxygen available to the tissues at any given oxygen tension (1). There is consequently less need for increasing the cardiac output, a mechanism which would serve the same purpose but at a greater cost to body economy.
Conversely the suppression of the hypoxic stress in highlanders moved to sea level causes a rapid decrease in the $\mathrm{P}_{50}$. The response therefore appears to relate to oxygen supply and tissue oxygen tension and does not correlate with the level of hemoglobin.

The similar changes in oxygen dissociation of intact red cells and hemolysates suggests that the effect is not a function of the red cell membrane. It may, however, be related to the concomitant changes in red cell organic phosphate. Benesch et al. (3) and Garby and deVerdier (10) have shown that 2,3-DPG forms a complex with purified deoxyhemoglobin and in doing so, reduces the affinity of hemoglobin for oxygen. The parallel changes in 2,3-DPG and oxygen dissociation found in subjects moved from one altitude to another might well represent the same phenomenon. Other examples of this relationship exists. Akerblom, deVerdier, Garby, and Hogman (5) found a linear relationship between $\mathrm{P}_{60}$ and the sum of the molar concentrations of 2,3-DPG and ATP in stored blood; others have observed progressive decreases in organic phosphate and increases in hemoglobin affinity for oxygen during storage (11-14). Likewise, blood transfused after storage shows a return to normal of both oxygen dissociation (2) and organic phosphate (4) in vivo. In anemic states oxygen dissociation curves shift to the right (5-7) and in at least one type of anemia the organic phosphate has been reported as increased (8).

Benesch and Benesch (9) have suggested a

TABLE I

Group I

\begin{tabular}{llcccc}
\hline Time at high altitude, $h r$ & & -12 & +36 & +132 & +204 \\
\hline $\mathrm{P}_{50}(7.4), \mathrm{mm} H g$ & whole blood & $26.6 \pm 0.3$ & $31.0 \pm 0.4$ & $31.1 \pm 0.5$ & $27.3 \pm 0.8$ \\
& hemolysate & $18.5 \pm 1.2$ & $20.7 \pm 1.2$ & $22.2 \pm 1.2$ & $20.3 \pm 0.9$ \\
Organic phosphate & & & & \\
2,3-DPG & $\mu \mathrm{gP} / \mathrm{ml}$ blood & $90 \pm 11$ & $142 \pm 8$ & $140 \pm 10$ & $87 \pm 14$ \\
& $\mu \mathrm{gP} / \mathrm{g} \mathrm{Hb}$ & $588 \pm 74$ & $912 \pm 80$ & $870 \pm 98$ & $554 \pm 107$ \\
& Molar ratio & $0.61 \pm 0.07$ & $0.94 \pm 0.08$ & $0.90 \pm 0.10$ & $0.57 \pm 0.11$ \\
ATP & $\mu \mathrm{gP} / \mathrm{ml}$ blood & $36 \pm 6.7$ & $45 \pm 3.6$ & $47 \pm 4.6$ & $37 \pm 3.3$ \\
& $\mu \mathrm{gP} / \mathrm{g}$ Hb & $238 \pm 41$ & $285 \pm 20$ & $302 \pm 42$ & $234 \pm 23$ \\
& Molar ratio & $0.16 \pm 0.03$ & $0.20 \pm 0.01$ & $0.21 \pm 0.03$ & $0.16 \pm 0.01$ \\
Fraction 1 & $\mu \mathrm{gP} / \mathrm{ml}$ blood & $14 \pm 2.2$ & $17 \pm 0.9$ & $15.7 \pm 1.0$ & $14.0 \pm 2.4$ \\
Fraction 2 & $\mu \mathrm{gP} / \mathrm{ml}$ blood & $12 \pm 2.6$ & $13 \pm 2.0$ & $12.8 \pm 1.7$ & $12.0 \pm 4.0$ \\
\hline
\end{tabular}


TABLE II

Group II

\begin{tabular}{llcccc}
\hline Time at low altitude, $h r$ & & -36 & +12 & +36 & +84 \\
\hline $\mathrm{P}_{50}(7.4) \mathrm{mm} \mathrm{Hg}$ & Whole blood & $30.7 \pm 0.6$ & $28.6 \pm 0.5$ & $27.3 \pm 0.8$ & $28.3 \pm 0.6$ \\
& Hemolysate & $24.1 \pm 0.8$ & $22.0 \pm 1.1$ & $21.1 \pm 1.5$ & $22.5 \pm 1.0$ \\
Organic phosphate & & & & \\
$2,3 \mathrm{DPG}$ & $\mu \mathrm{gP} / \mathrm{ml}$ blood & $155 \pm 14$ & & $109 \pm 13$ & $87 \pm 14$ \\
& Molar ratio & $0.80 \pm 0.08$ & & $0.58 \pm 0.03$ & $0.49 \pm 0.08$ \\
ATP & $\mu \mathrm{gP} / \mathrm{ml}$ blood & $70 \pm 17$ & & $48 \pm 13$ & $38 \pm 12$ \\
& Molar ratio & $0.23 \pm 0.05$ & & $0.16 \pm 0.03$ & $0.13 \pm 0.04$ \\
Fraction 1 & $\mu \mathrm{gP} / \mathrm{ml}$ blood & $20 \pm 1.6$ & & $18 \pm 0.2$ & $12 \pm 1.9$ \\
Fraction 2 & $\mu \mathrm{gP} / \mathrm{ml}$ blood & $16 \pm 2.2$ & & $16 \pm 1.3$ & $10 \pm 2.6$ \\
\hline
\end{tabular}

sequence of events to account for the increase in 2,3-DPG in the anoxic state. Since organic phosphate reacts only with reduced hemoglobin, the greater the anoxia the greater the amount of reduced hemoglobin present and the larger the amount of 2,3-DPG bound. This binding depletes the soluble organic phosphate in the cell, and glycolysis is stimulated to produce more 2,3-DPG. Increased glycolysis and organic phosphate production has been shown to occur in vitro in deoxygenated blood (20). Such a mechanism would automatically control the balance between oxyhemoglobin and deoxyhemoglobin and thus would counteract the effects of an increase in reduced hemoglobin.

Although an increase in $\mathrm{pH}$ has been found to cause an increase in 2,3-DPG (21), the changes in 2,3-DPG observed in our two groups of subjects cannot be accounted for by the acid-base status usually observed in subjects going to altitude or in natives before and after descent to sea level. While it is a common finding that alkalosis develops rapidly and persists in lowlanders subjected to altitude hypoxia, it is also recognized that natives of the highland differ by maintaining a normal $\mathrm{pH}(22,23)$. Therefore, the increase in 2,3-DPG in lowlanders and the prevailing high level of organic phosphate in natives cannot be ascribed to the $\mathrm{pH}$. Furthermore, as natives do not become acidotic upon descending to sea level, their decrease in 2,3-DPG cannot be explained by such a mechanism.

\section{ACKNOWLEDGMENTS}

This work was supported by AEC Contract No. AT (45)2048, U. S. Public Health Service Grants 5-R01-HE-
06242, HE12174, and U. S. Army grant DA-ARO 49-092, 65 G-90.

\section{REFERENCES}

1. Aste-Salazar, H., and A. Hurtado. 1944. The affinity of hemoglobin for oxygen at sea level and at high altitudes. Am. J. Physiol. 142: 733.

2. Benesch, R., and R. E. Benesch. 1967. The effect of organic phosphates from the human erythrocyte on the allosteric properties of hemoglobin. Biochem. Biophys. Res. Commun. 26: 162.

3. Benesch, R., R. E. Benesch, and C. I. Yu. 1968. Reciprocal binding of oxygen and diphosphoglycerate by human hemoglobin. Proc. Natl. Acad. Sci. 59: 526.

4. Chanutin, A., and R. R. Curnish. 1967. Effect of organic and inorganic phosphates on the oxygen equilibrium of human erythrocytes. Arch. Biochem. Biophys. 121: 96.

5. Akerblom, O., C.-H. deVerdier, L. Garby, and C. Hogman. 1968. Restoration of defective oxygentransport function of stored red blood cells by addition of inosine. Scand. J. Clin. Lab. Invest. 21: 245.

6. Lenfant, C., and K. Johansen. 1964. Gas transport by hemocyanin-containing blood of the Cephalopod Octopus dofleini. Am. J. Physiol. 209: 991.

7. Severinghaus, J. W. 1966. Blood gas calculator. J. Appl. Physiol. 21: 1108.

8. Robinson, M. A., P. B. Loder, and G. C. deGruchy. 1961. Red-cell metabolism in non-spherocytic congenital haemolytic anaemia. Brit. J. Haematol. 7: 327.

9. Bartlett, G. R. 1959. Phosphorus assay in column chromatography. J. Biol. Chem. 234: 466.

10. Garby, L., and C.-H. deVerdier. 1968. Binding of ATP and 2,3 DPG to hemoglobin-effect on glycolysis. Folia Haematol. 89: 721.

11. Rapoport, S. 1947. Dimensional, osmotic and chemical changes of erythrocytes in stored blood. I. Blood preserved in sodium citrate, neutral, and acid citrateglucose (ACD) mixtures. J. Clin. Invest. 26: 591.

12. Valtis, D. J., and A. C. Kennedy. 1954. Defective gastransport function of stored red blood cells. Lancet. 1: 119 . 
13. Gullbring, B., and G. Strom. 1956. Changes in oxygen-carrying function of human hemoglobin during storage in cold acid-citrate-dextrose solution. Acta Med. Scand. 155: 413.

14. Gabrio, B. W., A. R. Stevens, Jr., and C. A. Finch. 1954. Erythrocyte preservation. III. The reversibility of the storage lesion. J. Clin. Invest. 33: 252.

15. Mulhausen, R., P. Astrup, and K. Kjeldsen. 1967. Oxygen affinity of hemoglobin in patients with cardiovascular diseases, anemia and cirrhosis of the liver. Scand. J. Clin. Lab. Invest. 19: 291.

16. Kennedy, A. C., and D. J. Valtis. 1954. The oxygen dissociation curve in anemia of various types. $J$. Clin. Invest. 33: 1372.

17. Rodman, T., H. P. Close, and M. K. Purcell. 1960. Oxyhemoglobin dissociation curve in anemia. Ann. Internal Med. 52: 295.
18. Hurt, G. A., and A. Chanutin. 1964. Organic phosphate compounds of erythrocytes from individuals with uremia. J. Lab. Clin. Med. 64: 675.

19. Benesch, R., and R. E. Benesch. 1968. Oxygenation and ion transport in red cells. Science. 160: 83.

20. Asakura, T., Y. Sato, S. Minakami, and H. Yoshikawa. 1966. Effect of deoxygenation of intracellular hemoglobin on red cell glycolysis. J. Biochem. 59: 524 ,

21. Guest, G. M., and S. Rapoport. 1939. Role of acid soluble phosphorus compounds in red blood cells. Am. J. Diseases Children. 58: 1072.

22. Hurtado, A., and H. Aste-Salazar. 1948. Arterial blood gases and acid-base balance at sea level and at high altitudes. J. Appl. Physiol. 1: 304.

23. Lahiri, S., and J. S. Milledge. 1967. Acid base in Sherpa altitude residents and lowlanders at $4880 \mathrm{~m}$. Resp. Physiol. 2: 323. 